\title{
Vanadate treatment rapidly improves glucose transport and activates 6-phosphofructo-1-kinase in diabetic rat intestine
}

\author{
K.L. Madsen, D. Ariano, R.N. Fedorak \\ Division of Gastroenterology, Department of Medicine, University of Alberta, Edmonton, Alberta, Canada
}

Summary The effect of oral vanadate on intestinal sodium-dependent glucose transport and 6-phosphofructo-1-kinase (EC 2.7.1.11) activity was examined in male Sprague-Dawley rats following a 30 -day period of non-treated streptozotocin-induced diabetes. Non-treated diabetic rats were hyperglycaemic and demonstrated increased intestinal sodium-dependent glucose transport and Na,K-ATPase activity compared with controls. These increases were associated with a significant decrease in the total activity and activity ratios (activity at $0.5 \mathrm{mmol} / \mathrm{l}$ fructose 6 -phosphate at $\mathrm{pH} 7.0$ /activity at $\mathrm{pH} 8.0$ ) of intestinal 6phosphofructo-1-kinase and decreased levels of fructose 2,6-bisphosphate. Supplementation of drinking water with vanadate $(0.5 \mathrm{mg} / \mathrm{ml})$ resulted in a rapid decline in blood glucose levels to a slightly hyperglycaemic level. Jejunal glucose transport and $\mathrm{Na}, \mathrm{K}$ ATPase activity were normalized after $48 \mathrm{~h}$ of vanadate treatment. In contrast, ileal glucose transport was significantly reduced $12 \mathrm{~h}$ following beginning vanadate treatment even though $\mathrm{Na}, \mathrm{K}$-ATPase activity did not normalize until $36 \mathrm{~h}$ later. $\mathrm{K}_{\mathrm{m}}$ was significantly decreased in both jejunum and ileum by vanadate treatment indicating an increased affinity of the sodium-dependent intestinal glucose transporter for glucose. 6-phosphofructo-1-kinase total activity and susceptibility to ATP inhibition was completely re- stored after $12 \mathrm{~h}$ of vanadate treatment. This increase was associated with a rise in fructose 2,6-bisphosphate levels. Fasting rats for $12 \mathrm{~h}$ had no effect on glucose transport or 6-phosphofructo-1-kinase activity, indicating the anorectic effect of vanadate was not responsible for changes in either parameter. In contrast, cycloheximide prevented both the rise in 6phosphofructo-1-kinase activity and the rise in fructose 2,6-bisphosphate levels, and the subsequent reduction in glucose transport, indicating a requirement for protein synthesis. The removal of vanadate resulted in an immediate return to pre-treatment blood glucose levels. In contrast, intestinal glucose transport and 6-phosphofructo-1-kinase activity remained at treatment levels up until $72 \mathrm{~h}$, indicating that oral vanadate treatment can have prolonged beneficial effects on intestinal function. In conclusion, the treatment of streptozotocin-induced diabetic rats with oral vanadate results in an activation of 6-phosphofructo-1-kinase coupled with a normalization of intestinal sodium-dependent glucose transport. Vanadate may thus have a beneficial effect on intestinal function and may prove useful as oral adjunctive diabetic therapy. [Diabetologia (1995) 38: 403-412]

Key words Glucose, intestine, vanadate, 6-phosphofructo-1-kinase.
Received: 12 July 1994 and in revised form: 7 October 1994

Abbreviations: $\mathrm{PFK}_{1}$, 6-phosphofructo-1-kinase; SGLT, $\mathrm{Na}^{+}$dependent glucose cotransporter; $\mathrm{J}_{\max }$, maximum transport rate; $K_{\mathrm{m}}$, carrier affinity; STZ, streptozotocin; 3-0-MG, 3-0methyl-D-glucopyranoside; PD, potential difference; GLUT2, glucose transporter 2; BBMV, brush border membrane vesicles Corresponding author: Dr. K. Madsen, Division of Gastroenterology, 519 Robert Newton Building, University of Alberta, Edmonton, Alberta, Canada T6G 2C2
Streptozotocin-induced (STZ) diabetes has been shown to result in an enhanced active intestinal absorption of glucose due to an increase in brush border Na-dependent glucose transporters (SGLT) [1] and basolateral membrane facilitated glucose carriers (GLUT2) [2, 3]. In addition, a reduction in enterocyte glucose utilization is seen in diabetes mellitus, primarily due to a decrease in the activity of 6-phosphofructo-1-kinase $\left(\mathrm{PFK}_{1}\right)$, [EC 2.7.1.11] which re- 
sults in an indirect increase in glucose absorption [4]. The consequences of such an increase in intestinal glucose absorption may aggravate diabetes due to the enhanced rate of the postprandial rise in serum glucose.

Oral vanadate treatment has been demonstrated to have a serum glucose-lowering effect in the STZ diabetic rat model [5] and in genetic insulin-resistance animal models $[6,7]$. Oral vanadate has also been shown to reduce $\mathrm{Na}$-dependent glucose transport in the small intestine in normal rats and prevent the increase in transport from occurring in STZ-diabetic rats [8]. While there is evidence to suggest that oral vanadate is effective in restoring $\mathrm{Na}$-dependent glucose transport to normal levels in the STZ-diabetic rat model [9], there have been no studies done to examine the effects of oral vanadate on intestinal $\mathrm{PFK}_{1}$ activity and no studies to determine whether the jejunum and ileum response to vanadate is similar. Both a down-regulation of transport and an increase in glucose utilization, as a consequence of an increased PFK $_{1}$ activity, would be necessary to effectively decrease overall glucose absorption. In addition, it is not known if vanadate-induced intestinal effects are a consequence of decreasing blood glucose levels, or are due to a direct action of vanadate on intestinal enterocytes.

The purpose of this study was thus to examine the effects of oral vanadate treatment on $\mathrm{Na}$-dependent glucose transport and $\mathrm{PFK}_{1}$ activity in jejunum and ileum of the STZ-induced diabetic rat model, and to determine if these effects are linked with blood glucose levels.

\section{Materials and methods}

Materials. Streptozotocin was obtained from Upjohn (Don Mills, Ontario, Canada). Vanadate $\left(\mathrm{V}_{2} \mathrm{O}_{5}\right)$ was purchased from Fisher Scientific (Edmonton, Alberta, Canada). D-[1$\left.{ }^{3} \mathrm{H}(\mathrm{N})\right]$-glucose $(15.5 \mathrm{Ci} / \mathrm{mmol})$ was obtained from New England Nuclear (Boston, Mass., USA). The remainder of chemicals were reagent grade and were obtained from Sigma Chemical Company (St Louis, Mo., USA).

\section{Animal model}

Induction of diabetes. Diabetes was induced in male SpragueDawley rats $(300-400 \mathrm{~g})$ via a single i. p. dose of STZ $(65 \mathrm{mg} /$ $\mathrm{kg}$ ). Blood glucose was measured $24 \mathrm{~h}$ after the STZ injection and at the time of study using an Ames reflectance photometer and glucose reagent strips (Ames Division, Miles Laboratory, Elkhart, Ind., USA). Only diabetic rats with hyperglycaemia of over $18 \mathrm{mmol} / \mathrm{l}$ were entered into the study.

Vanadate administration. Following a 30-day period of nontreated diabetes, vanadate $(0.5 \mathrm{mg} / \mathrm{ml})$ was added to the drinking water of rats for 7 consecutive days. In untreated diabetic animals, blood glucose levels were measured at 08.00-09.00 hours. Vanadate treatment was begun immediately thereafter and 24-h-blood glucose levels were measured the following morning at 08.00-09.00 hours. For $12 \mathrm{~h}$ blood glucose levels, vanadate treatment was begun at $08.00-09.00$ hours, and blood glucose levels and experiments performed the following morning at $08.00-09.00$ hours. Fasted animals had their food removed for the same time periods (08.00-20.00 hours). All animals, except for the fasted group, were allowed access to the standard rat diet ad libitum, and housed in a light-cycled animal care facility.

Three groups were studied: (1) age-matched controls; (2) non-treated diabetic; and (3) vanadate-supplemented diabetic. In the vanadate-treated group, rats were studied at various time intervals after vanadate was added to the drinking water.

\section{Intact mucosal sheet transport experiments}

Segments of jejunum and ileum from which the outer muscle layer had been removed were mounted in Ussing Chambers and bathed on both sides with a bicarbonate-Ringer's solution containing $20 \mathrm{mmol} / 1$ fructose circulated with $5 \% \quad \mathrm{CO}_{2} / 95 \%$ $\mathrm{O}_{2}(\mathrm{pH} 7.4)$ at $37^{\circ} \mathrm{C}$. The spontaneous transepithelial potential difference (PD) and short circuit current $\left(\mathrm{I}_{\mathrm{sc}}\right)$ was measured. Maximal transport capacity $\left(\mathrm{J}_{\text {max }}\right)$ and carrier affinity $\left(\mathrm{K}_{\mathrm{m}}\right)$ were determined for 3-0-methyl-D-glucopyranoside (3$0-\mathrm{MG}$ ) (concentration range $0.5-60 \mathrm{mmol} / \mathrm{l}$ ) by measurement of concentration-dependent short circuit current $\left(\mathrm{I}_{\mathrm{sc}}\right)$ as previously described [10].

\section{Enzyme analysis}

Rats were killed with a pentobarbital overdose $(240 \mathrm{mg} / \mathrm{kg})$ and the jejunum and ileum removed and flushed with ice cold $0.9 \% \mathrm{NaCl}$. The mucosa was scraped off with a glass slide, weighed, and homogenized in a 1:10 volume of extraction buffer using a Polytron homogenizer.

$\mathrm{Na}, \mathrm{K}$-ATPase activity. $\mathrm{Na}, \mathrm{K}$-ATPase activity was assessed by incubating samples $(50 \mu \mathrm{g}$ protein $/ \mathrm{ml})$ in $25 \mathrm{mmol} / \mathrm{l}$ imidazole, $1 \mathrm{~mol} / 1 \mathrm{EGTA}$, and $0.6 \mathrm{mg}$ deoxycholate $/ \mathrm{mg}$ protein for $15 \mathrm{~min}$ at $37^{\circ}$ to ensure the disruption of membranes and ligand access to all ouabain binding sites. To start the reaction, aliquots of the homogenate were added to buffer containing $50 \mathrm{mmol} / 1$ histidine, $130 \mathrm{mmol} / 1 \mathrm{NaCl}_{2} 20 \mathrm{mmol} / \mathrm{K} \mathrm{KCl}$, $4 \mathrm{mmol} / 1 \mathrm{MgCl}$, and $3 \mathrm{mmol} / 1 \mathrm{ATP}(\mathrm{pH} 7.4$ ). The reaction was allowed to proceed for $15 \mathrm{~min}$ at $37^{\circ} \mathrm{C}$ and then quenched by the addition of ice cold $8 \%$ perchloric acid. Samples were centrifuged, and inorganic phosphate levels were measured using the method of Radominski-Pyret et al. [11]. Samples to which protein was added after the reaction was terminated were used as blanks. Na,K-ATPase activity was calculated as the difference between inorganic phosphate released in the presence and absence of ouabain. Ouabain-sensitive ATP hydrolysis was in the range of $7 \%$ to $22 \%$ of total ATP hydrolysis, and this figure did not differ between the animal groups. Na,K-ATPase activity was based on the protein content of samples as measured using the Bradford technique [12].

6-phosphofructo-1-kinase activity. Total activity of the ratelimiting enzyme of glycolysis, $\mathrm{PFK}_{1}$ (EC 2.7.1.11) was measured using the method described by Ling et al. [13]. Intestinal mucosa was removed and immediately frozen in liquid $\mathrm{N}_{2}$ for measurement of $\mathrm{PFK}_{1}$ and fructose 2,6-bisphosphate levels. To measure $\mathrm{PFK}_{1}$, the frozen tissue was homogenized with 5 vol (volume/weight) of icecold extraction buffer solution 
A

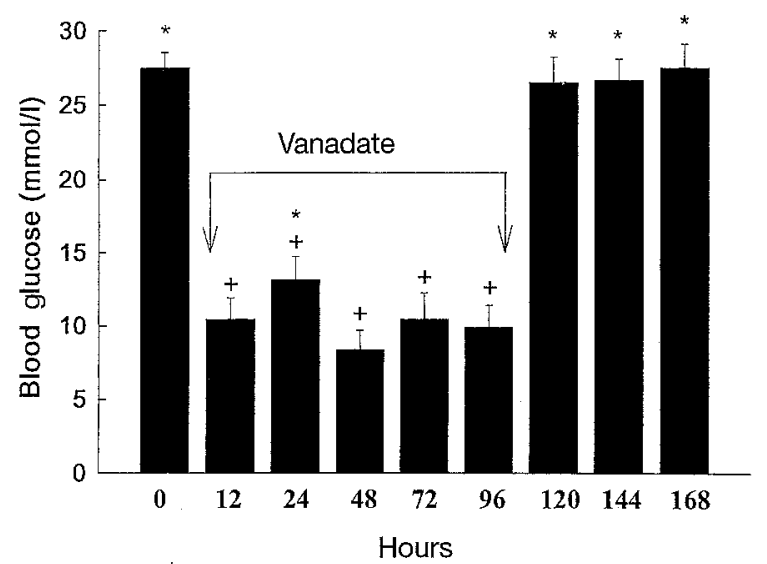

B

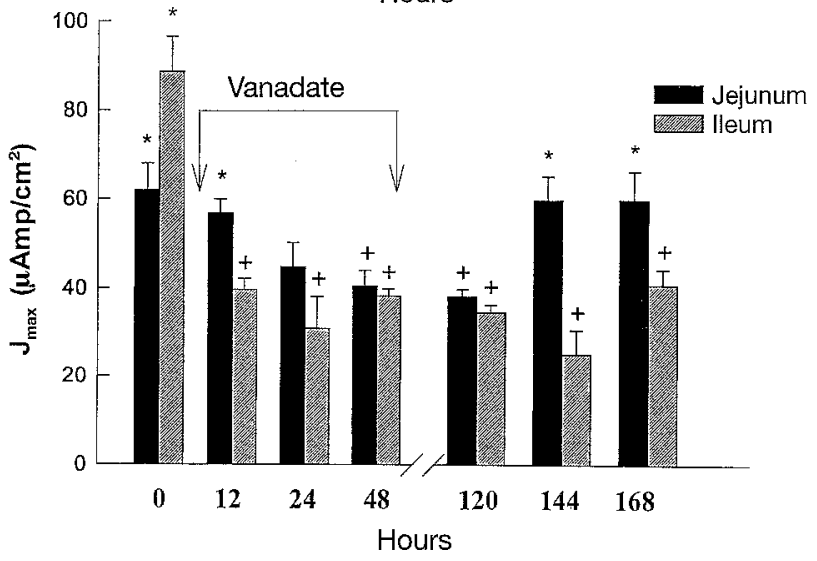

Fig. 1A, B. Blood glucose levels in diabetic rats following the initiation of vanadate treatment (time 0 ) and the removal of vanadate therapy ( $96 \mathrm{~h}$ later) (A). Vanadate treatment resulted in a rapid decline of blood glucose within $12 \mathrm{~h}$ to a slightly hyperglycaemic level whereby levels stabilized. Removal of vanadate treatment resulted in a return to pre-treatment levels within $24 \mathrm{~h} . * p<0.05$ relative to controls; $+p<0.05$ relative to non-treated diabetics. Jejunal and ileal $\mathrm{J}_{\max }$ for glucose transport measured in intact sheets of tissue in Ussing chambers as a response to vanadate treatment $(\mathbf{B})$. Jejunal $\mathrm{J}_{\max }$ was normalized after $48 \mathrm{~h}$ of vanadate treatment. Ileal $\mathrm{J}_{\max }$ rapidly fell to near normal levels after $12 \mathrm{~h}$. Jejunal $\mathrm{J}_{\max }$ increased to pre-treatment levels $48 \mathrm{~h}$ following removal of vanadate. Ileal $\mathrm{J}_{\max }$ began to increase to pre-treatment levels $72 \mathrm{~h}$ following removal of vanadate. ${ }^{*} p<0.05$ relative to controls; $+p<0.05$ relative to untreated diabetics. Each data point represents the mean \pm SEM of at least eight animals

$(50 \mathrm{mmol} / 1 \mathrm{Tris}-\mathrm{HCl} ; 100 \mathrm{mmol} / 1 \mathrm{NH}) \mathrm{SO}_{4} ; 30 \mathrm{mmol} / 1 \mathrm{KF}$; $2 \mathrm{mmol} / 1 \mathrm{DTT} ; 1 \mathrm{mmol} / 1 \mathrm{EDTA} ; 1 \mathrm{mmol} / 1$ phenylmethanesulphonyl fluoride; and $0.5 \mathrm{mg} / \mathrm{ml}$ soybean trypsin inhibitor). Tissue homogenates were centrifuged for $30 \mathrm{~min}$ at $75000 \mathrm{~g}$ at $4^{\circ} \mathrm{C}$. Pellets were discarded and the supernatant used for assay. Activity of PFK $_{1}$ is expressed as the maximal activity at $\mathrm{pH} 8.0$ where the enzyme is not subject to allosteric regulation [18]. The regulatory properties of $\mathrm{PFK}_{1}$ are presented as the activity ratio $\left(\mathrm{v}_{0.5} / \mathrm{V}\right)$ where $\mathrm{v}_{0.5}$ is the suboptimal activity at $\mathrm{pH} 7.0$ in the presence of $2.5 \mathrm{mmol} / \mathrm{l} \mathrm{ATP}$ and $0.5 \mathrm{mmol} / \mathrm{l}$ fructose 6-phosphate under the conditions defined by Hussey et al. [14] and $\mathrm{V}$ is the total activity at $\mathrm{pH} 8.0$.

Fructose 2,6-bisphosphate levels. Fructose 2,6-bisphosphate was measured in rat jejunal and ileal mucosa using the method of Van Schaftingen et al. [15] with stimulation to pyrophos- phate-dependent phosphofructokinase (EC 2.7.1.90) purified from potato tubers.

\section{Brush border membrane studies}

Vesicle preparation. Brush border membrane vesicles (BBMV) were prepared from the proximal and distal small intestine by a $\mathrm{CaCl}_{2}$ precipitation method as previously described [16]. Purification was assessed through the measurement of sucrase specific activity in the original homogenate and in the final preparation using a coupled glucose 6-phosphate dehydrogenase reaction (Boehringer Mannheim, Dorval, QC, Canada). Sucrase activity was, on average, enriched $14.8 \pm 2.6$ fold in the BBMV preparations in comparison to whole homogenates, and no difference was seen between groups. The degree of $\mathrm{Na}, \mathrm{K}$-ATPase enrichment ranged from 0.6 to 1.4 in all groups, indicating negligible contamination by basolateral membranes.

Transport studies. Glucose uptake studies were carried out at room temperature using the rapid filtration method of Hopfer et al. [17]. Initial uptake rates were measured at an incubation time of $5 \mathrm{~s}$ at concentrations of glucose in the incubation medium ranging from $50 \mu \mathrm{mol} / / \mathrm{l}$ to $4 \mathrm{mmol} / 1$. To start the reaction, $10 \mu \mathrm{l}$ of freshly prepared vesicles was added to $50 \mu \mathrm{l}$ of incubation buffer containing varying concentrations of $\left.{ }^{3} \mathrm{H}\right]$ glucose, $100 \mathrm{mmol} / 1 \mathrm{NaSCN}, 50 \mathrm{mmol} / \mathrm{l}$ mannitol, and $20 \mathrm{mmol} / \mathrm{l} \mathrm{HE}-$ PES; pH 7.5 to start the reaction. The reaction was stopped at $5 \mathrm{~s}$ by the addition of $3 \mathrm{ml}$ of icecold stop solution $(20 \mathrm{mmol} / \mathrm{l}$ HEPES, $100 \mathrm{mmol} / \mathrm{l} \mathrm{NaCl}$, and $150 \mathrm{mmol} / \mathrm{l}$ mannitol). The resultant mixture was then filtered through a prewetted and chilled $0.45-\mu \mathrm{m}$ nitrocellulose filter (Millipore) and washed with $9 \mathrm{ml}$ of stop solution. Filters were dissolved in $10 \mathrm{ml}$ scintillation fluid and counted. Non-specific binding of $\left[{ }^{3} \mathrm{H}\right]$-glucose to filters was measured by filtration of incubation medium, stop solution, and vesicles without allowing mixing of medium and vesicles, and all results were subsequently corrected. Experiments were performed on at least four different freshly prepared vesicle preparations. Sodium-dependent glucose uptake rates were calculated by subtracting the sodium-independent component measured in the presence of $\mathrm{KSCN}$ from the total seen in the presence of NaSCN. Uptake data is reported as nanomoles of glucose per minute per milligram of vesicle protein.

\section{Cycloheximide experiments}

To determine if protein synthesis was required for the vanadate-induced effects, rats were injected with a cycloheximide solution $(1 \mathrm{~g} / 1$ in $0.9 \% \mathrm{NaCl}-3 \mathrm{ml} / \mathrm{kg}) 1 \mathrm{~h}$ before vanadate therapy was initiated as described by Crouzoulon and Dandrifosse [18]. Control animals received saline alone. Measurements were taken $12 \mathrm{~h}$ following administration, and compared with those obtained from diabetic rats and control rats receiving either cycloheximide or vanadate alone.

\section{Statistical analysis}

The results were expressed as means \pm SEM. Statistical significance of the data at the $95 \%$ confidence level was determined according to ANOVA using the statistical software package SIGMASTAT (Jandel Scientific, San Rafael, Calif., USA). Specific differences were tested using the Student-Newman- 
Table 1. Na,K-ATPase activity, kinetic constants for Na-dependent glucose transport in BBMV, and membrane PD in response to vanadate treatment

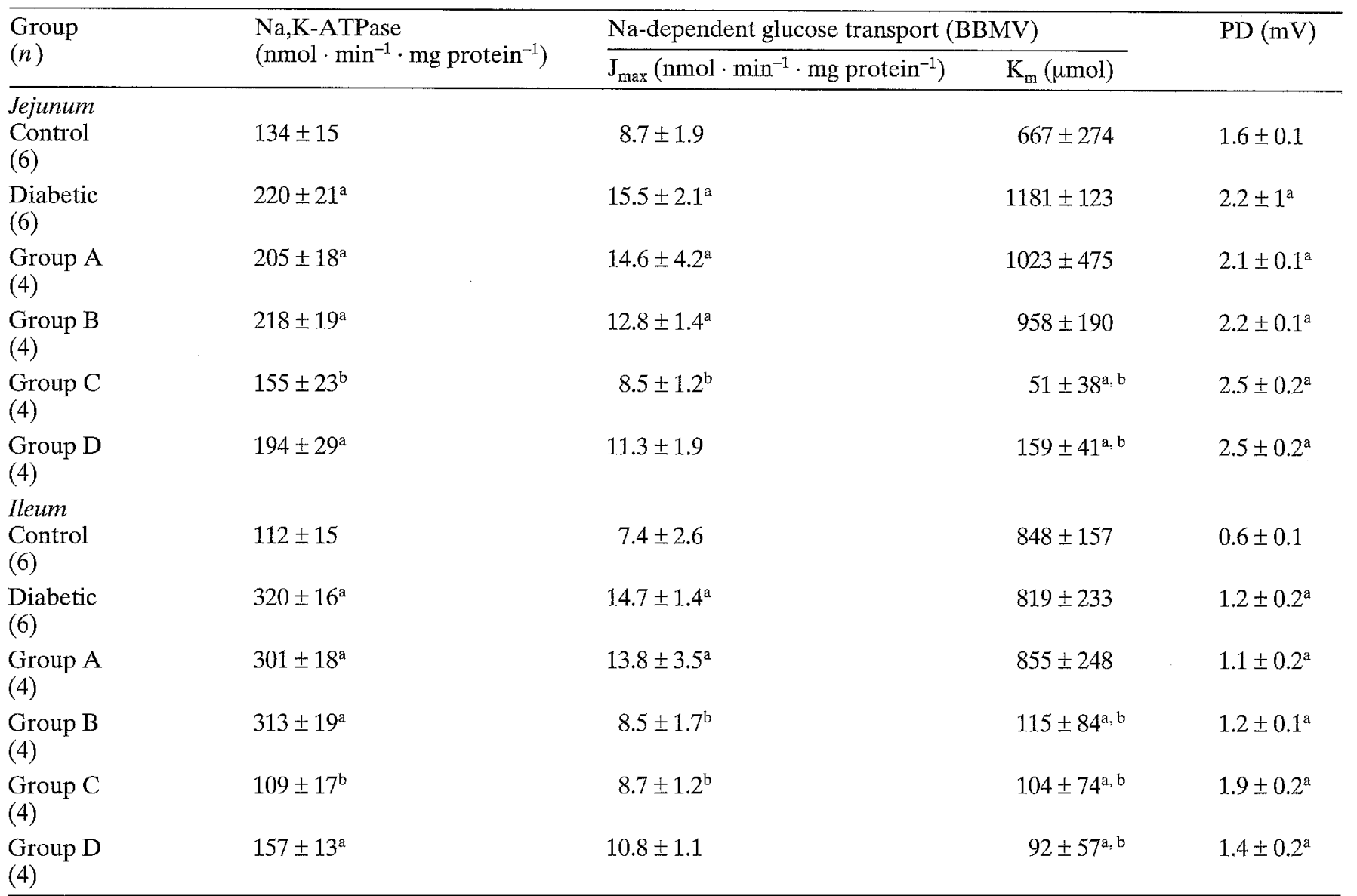

Values are means \pm SEM. Treatment groups: Group A, diabetic animals fasted for $12 \mathrm{~h}$; Group B, diabetic animals receiving vanadate for $12 \mathrm{~h}$; Group $\mathrm{C}$, diabetic animals receiving vanadate for $48 \mathrm{~h}$; Group $\mathrm{D}$, diabetic animals treated with vana- date, $72 \mathrm{~h}$ after vanadate has been removed.

${ }^{a} p<0.05$ relative to controls;

${ }^{\mathrm{b}} p<0.05$ relative to non-treated diabetics
Keuls analysis as a post hoc test. Curve-fitting and parameter estimation for non-linear relationships were performed with data points weighted inversely to within-sample variances at each concentration [19].

\section{Results}

Animal profile. Streptozotocin-treated rats demonstrated elevated blood glucose levels within $24 \mathrm{~h}$ of injection ( $>18 \mathrm{mmol} / \mathrm{l}$ ) and remained hyperglycaemic for the duration of the study. Body weight at the time of diabetes induction did not differ between STZ treated $(351 \pm 12 \mathrm{~g})$ and non-treated $(355 \pm 14)$ rats. At 30 days (the time of experimentation) after the induction of diabetes, the average body weight $(371 \pm 10 \mathrm{~g})$ and blood glucose $(>18 \mathrm{mmol} / \mathrm{l})$ of diabetic rats was significantly different $(p<0.05)$ from those of age-matched control rats $(421 \pm 14 \mathrm{~g}$; $5.6 \pm 0.6 \mathrm{mmol} / \mathrm{l})$.

Rats receiving vanadate in their drinking water showed a rapid decrease in blood glucose levels with- in $12 \mathrm{~h}$ to a slightly hyperglycaemic point where levels stabilized for the duration of vanadate supplementation (Fig. 1A). Removal of vanadate resulted in an increase in blood glucose levels to pre-treatment hyperglycaemic levels within $24 \mathrm{~h}$.

Intact mucosal sheet transport studies. When measured in intact sheets of tissue in Ussing chambers, non-treated diabetic rats demonstrated an increase $(p<0.02)$ in $\mathrm{J}_{\max }$ for $\mathrm{Na}$-dependent jejunal $\left(61.9 \pm 6.1 \mu \mathrm{Amp} / \mathrm{cm}^{2}\right)$ and ileal $(88.6 \pm 8.0 \mu \mathrm{Amp} /$ $\mathrm{cm}^{2}$ ) glucose transport in comparison with results obtained from age-matched control rats (jejunum: $42.1 \pm 5.2$; ileum: $\left.20.5 \pm 1.5 \mu \mathrm{Amp} / \mathrm{cm}^{2}\right)$. PD was also increased $(p<0.05)$ in diabetic tissue (jejunum: $2.2 \pm 0.2$; ileum: $1.2 \pm .2 \mathrm{mV}$ ) compared with control tissue (jejunum: $1.5 \pm 1$; ileum: $0.5 \pm .1 \mathrm{mV}$ ). Upon initiation of vanadate treatment, there was a marked difference in the way the jejunum and ileum responded. As shown in Fig. $1 \mathrm{~B}, \mathrm{~J}_{\max }$ for Na-dependent jejunal glucose transport fell gradually and was normalized after $48 \mathrm{~h}$ of treatment. In contrast, the ileum re- 
Table 2. $\mathrm{PFK}_{1}$ activity and fructose 2,6-bisphosphate levels in response to vanadate treatment

\begin{tabular}{|c|c|c|c|c|}
\hline \multirow{2}{*}{$\begin{array}{l}\text { Group } \\
(n)\end{array}$} & \multicolumn{3}{|l|}{$\mathrm{PFK}_{1}$ activity } & \multirow{2}{*}{$\begin{array}{l}\text { Fructose 2,6-bisphosphate } \\
\text { (nmol/g dry weight) }\end{array}$} \\
\hline & $\begin{array}{l}\text { Total activity } \\
\left(\mathrm{nmol} \cdot \mathrm{min}^{-1}\right.\end{array}$ & $m g$ protein $^{-1}$ ) & $\begin{array}{l}\text { Activity ratio } \\
(\mathrm{v} 0.5 / \mathrm{V})\end{array}$ & \\
\hline $\begin{array}{l}\text { Jejunum } \\
\text { Control } \\
\text { (6) }\end{array}$ & $83.4 \pm 2.1$ & & $0.38 \pm 0.08$ & $12.7 \pm 1.2$ \\
\hline $\begin{array}{l}\text { Diabetic } \\
\text { (6) }\end{array}$ & $40.2 \pm 1.2^{\mathrm{a}}$ & & $0.20 \pm 0.06^{\mathrm{a}}$ & $6.2 \pm 1.5^{\mathrm{a}}$ \\
\hline $\begin{array}{l}\text { Group A } \\
\text { (4) }\end{array}$ & $30.2 \pm 2.1^{\mathrm{a}}$ & & $0.16 \pm 0.05^{\mathrm{a}}$ & $5.4 \pm 1.6^{\mathrm{a}}$ \\
\hline $\begin{array}{l}\text { Group B } \\
\text { (4) }\end{array}$ & $79.3 \pm 1.6^{\mathrm{b}}$ & & $0.40 \pm 0.09^{b}$ & $13.5 \pm 1.4^{\mathrm{b}}$ \\
\hline $\begin{array}{l}\text { Group C } \\
\text { (4) }\end{array}$ & $71.4 \pm 0.7^{b}$ & & $0.38 \pm 0.08^{b}$ & $13.1 \pm 0.9^{\mathrm{b}}$ \\
\hline $\begin{array}{l}\text { Group D } \\
\text { (4) }\end{array}$ & $52.9 \pm 2.4$ & & $0.28 \pm 0.09$ & $9.4 \pm 1.3$ \\
\hline $\begin{array}{l}\text { Ileum } \\
\text { Control } \\
\text { (6) }\end{array}$ & $79.5 \pm 2.2$ & & $0.36 \pm 0.07$ & $11.2 \pm 1.4$ \\
\hline $\begin{array}{l}\text { Diabetic } \\
\text { (6) }\end{array}$ & $33.0 \pm 3.4^{\mathrm{a}}$ & & $0.24 \pm 0.08^{\mathrm{a}}$ & $5.2 \pm 1.0^{\mathrm{a}}$ \\
\hline $\begin{array}{l}\text { Group A } \\
\text { (4) }\end{array}$ & $26.2 \pm 3.8^{\mathrm{a}}$ & & $0.18 \pm 0.07^{\mathrm{a}}$ & $3.5 \pm 1.8^{\mathrm{a}}$ \\
\hline $\begin{array}{l}\text { Group B } \\
\text { (4) }\end{array}$ & $60.9 \pm 3.5^{\mathrm{b}}$ & & $0.38 \pm 0.06^{b}$ & $12.4 \pm 1.3^{\mathrm{b}}$ \\
\hline $\begin{array}{l}\text { Group C } \\
\text { (4) }\end{array}$ & $58.4 \pm 0.6^{\mathrm{b}}$ & & $0.38 \pm 0.07^{\mathrm{b}}$ & $11.8 \pm 1.5^{b}$ \\
\hline $\begin{array}{l}\text { Group D } \\
\text { (4) }\end{array}$ & $47.1 \pm 3.3$ & & $0.30 \pm 0.06$ & $9.5 \pm 1.2$ \\
\hline
\end{tabular}

Values are means \pm SEM. Treatment groups: Group A, diabetic animals fasted for $12 \mathrm{~h}$; Group B, diabetic animals receiving vanadate for $12 \mathrm{~h}$; Group $\mathrm{C}$, diabetic animals receiving vanadate for $48 \mathrm{~h}$; Group D, diabetic animals treated with vanadate, $72 \mathrm{~h}$ after vanadate has been removed. The total activity of $\mathrm{PFK}_{1}$ was measured under optimal conditions at $\mathrm{pH} 8$ where the enzyme is not susceptible to allosteric regulation.
The susceptibility of $\mathrm{PFK}_{1}$ to inhibition by ATP was measured by changes in the activity ratio (v0.5/V) of the activity determined at $\mathrm{pH} 7$ in the presence of $0.5 \mathrm{mmol} / 1$ fructose- $6-$ phosphate and $2.5 \mathrm{mmol} / 1$ at $\mathrm{pH} 7$.

${ }^{\mathrm{a}} p<0.05$ relative to controls; ${ }^{\mathrm{b}} p<0.05$ relative to non-treated diabetics sponded to vanadate supplementation with a rapid reduction in glucose $\mathrm{J}_{\max }$ within $12 \mathrm{~h}$. Both jejunal and ileal glucose transport was stabilized for the duration of the vanadate treatment $(96 \mathrm{~h}$ following initiation of treatment). In contrast, PD remained elevated (Table 1) and did not show any decrease in response to vanadate treatment, indicating that inhibition of the sodium electrochemical gradient was probably not responsible for the decrease in sodiumdependent glucose transport.

Removal of vanadate from the drinking water resulted in a rise in blood glucose levels to pre-treatment levels within $24 \mathrm{~h}$ (Fig. 1A). In contrast, jejunal glucose transport did not rise to pre-treatment levels until $48 \mathrm{~h}$ following removal of vanadate, and ileal glucose transport remained at treatment levels for $72 \mathrm{~h}$ following vanadate removal (Fig. 1B). Ileal glucose transport showed a rise to pre-treatment levels $120 \mathrm{~h}$ after the removal of vanadate (data not shown).
$N a, K$-ATPase activity. Vanadate has been shown to inhibit $\mathrm{Na}, \mathrm{K}-\mathrm{ATPase}$ activity in the intestine [20]. Thus, the decrease in intestinal Na-dependent glucose uptake observed in the intact sheets of tissue in the Ussing chambers may have simply resulted from a vanadate-induced inhibition of $\mathrm{Na}, \mathrm{K}$-ATPase. To examine this possibility, Na,K-ATPase was measured in tissue homogenant to determine if vanadate treatment was inhibiting enzyme activity. In contrast to the striking changes observed in glucose transport ileal $\mathrm{J}_{\max }$ after $12 \mathrm{~h}$ of vanadate treatment, there was no change seen in Na,K-ATPase enzyme activity for $48 \mathrm{~h}$. While this decrease in $\mathrm{Na}, \mathrm{K}$-ATPase activity occurred in parallel with the reduction of glucose transport in the jejunum, it occurred $36 \mathrm{~h}$ after ileal glucose transport had normalized. Thus, simple inhibition of $\mathrm{Na}, \mathrm{K}$-ATPase activity by vanadate treatment was not likely the cause of the down-regulation of ileal Na-dependent glucose transport. 
Following the removal of vanadate supplementation, both jejunal and ileal Na,K-ATPase activity began to increase, approaching pre-treatment levels within $72 \mathrm{~h}$ (Table 1 ).

Brush border membrane vesicle transport studies. Intestinal Na-dependent glucose transport in intestinal mucosal sheets is a function of the activity of glucose carriers on both the brush border membrane SGLT, and the basolateral membrane (GLUT2). We thus measured glucose transport in BBMV, devoid of GLUT2 transport protein, in order to confirm that the vanadate-induced normalization of transport seen in the intact sheets of intestinal tissue was due to a direct effect on SGLT, functional activity. Similar to the results seen in intact mucosal sheets, BBMV isolated from the jejunum and ileum of nontreated diabetic rats demonstrated a significant increase in glucose transport $\mathbf{J}_{\max }$ relative to controls (Table 1), while $\mathrm{K}_{\mathrm{m}}$ was not different. Table 1 shows the effects of vanadate treatment on BBMV isolated from diabetic rats. Again, as was seen with the intact mucosa sheet studies, jejunal glucose transport $\mathrm{J}_{\max }$ in BBMV was normalized $48 \mathrm{~h}$ following the beginning of vanadate treatment while ileal $\mathrm{J}_{\max }$ was normalized at $12 \mathrm{~h}$. These results indicate that the vanadate-induced transport response occurs at the level of the brush border membrane. In addition, $\mathrm{K}_{\mathrm{m}}$ was significantly decreased by vanadate treatment in both jejunum and ileum, indicating a greater affinity of SGLT, for glucose.

Diabetic animals are hyperphagic and vanadate supplementation has previously been shown to reduce food intake [8]. To determine if a reduction in food intake may have contributed to the down-regulation of glucose transport, BBMV were prepared from animals which had been fasted for $12 \mathrm{~h}$. As seen in Table 1, fasting had no effect on intestinal Na-dependent glucose transport. Thus, it is unlikely that a vanadate-induced reduction in food intake was the signal for a down-regulation of glucose transport.

Jejunal and ileal Na-dependent $\mathrm{J}_{\max }$ began to increase after $72 \mathrm{~h}$ following the removal of vanadate from their drinking water. In contrast, $\mathrm{K}_{\mathrm{m}}$ remained significantly decreased.

6-Phosphofructo-1-kinase activity and fructose 2,6bisphosphate levels. Glucose utilization in the small intestine is reduced in the diabetic state primarily as a result of a decrease in the activity of $\mathrm{PFK}_{1}$ (fructose-6-phosphate $\rightarrow$ fructose-1,6-bisphosphate) [4]. $\mathrm{PFK}_{1}$ itself is activated by micromolar concentrations of fructose 2,6-bisphosphate. In order to determine if oral vanadate treatment also increased the ability of the intestinal enterocyte to utilize glucose, in addition to decreasing the maximal glucose transport rate, we measured $\mathrm{PFK}_{1}$ activity and fructose 2,6-bisphosphate levels. In accordance with previous studies [4], we found jejunal and ileal enterocyte $\mathrm{PFK}_{1}$ total activity and activity ratio $\left(\mathrm{v}_{0.05} / \mathrm{V}\right)$ to be significantly reduced in diabetic rats in comparison to levels in age-matched control tissue (Table 2). Fructose 2,6-bisphosphate levels were also significantly depressed in diabetic rats (Table 2). Jejunal and ileal $\mathrm{PFK}_{1}$ total activity and the activity ratio $\left(\mathrm{v}_{0.5} / \mathrm{V}\right)$ and fructose 2,6-bisphosphate levels were normalized at $12 \mathrm{~h}$ after the initiation of vanadate treatment. To determine if a decrease in food intake was responsible for the effects of vanadate, $\mathrm{PFK}_{1} \mathrm{ac}$ tivity and fructose 2,6-bisphosphate levels were measured in diabetic animals fasted for $12 \mathrm{~h}$. Fasting resulted in a small decrease in both measurements (Table 2). Thus, it is not likely that a reduction in food intake as a consequence of the vanadate treatment was the cause of the increased $\mathrm{PFK}_{1}$ activity and fructose 2,6-bisphosphate levels.

$\mathrm{PFK}_{1}$ activity and fructose 2,6-bisphosphate levels began to fall towards pre-treatment levels $72 \mathrm{~h}$ following the cessation of vanadate treatment (Table 2).

Cycloheximide studies. To determine if vanadate-induced normalization of intestinal glucose transport and $\mathrm{PFK}_{1}$ activity was dependent upon protein synthesis, animals were injected with cycloheximide $(3 \mathrm{mg} / \mathrm{kg}$ ) concurrently with vanadate treatment for $12 \mathrm{~h}$. In the presence of cycloheximide, the activation of $\mathrm{PFK}_{1}$ activity and fructose 2,6-bisphosphate levels by vanadate was blocked in both jejunum and ileum (Table 3). The reduction in ileal glucose transport was also blocked by cycloheximide (Table 3 ). Diabetic and control animals injected with cycloheximide had no significant changes in either parameter.

\section{Discussion}

These results demonstrate that oral vanadate treatment rapidly improves $\mathrm{Na}$-dependent glucose transport in conjunction with an activation of $\mathrm{PFK}_{1}$ activity in diabetic rat intestine.

It is well documented that vanadate can prevent the changes produced in the small intestine by the induction of experimental diabetes [8] and this effect has generally been considered a secondary consequence of the reduction in hyperglycaemia induced by vanadate [9]. However, the concentration of vanadate used in this study $(0.5 \mathrm{mg} / \mathrm{ml})$ stabilized blood glucose levels at a slightly hyperglycaemic level, similar to results obtained by Sekar et al. [21], while PFK $_{1}$ activity was normalized along the entire small intestine, and glucose transport was normalized in the jejunum. This would suggest that these changes are not related to blood glucose levels and may reflect a direct cellular effect of vanadate. In addition, both glucose transport and $\mathrm{PFK}_{1}$ activity remained at 
Table 3. Effect of cycloheximide on $\mathrm{PFK}_{1}$ activity, fructose 2,6-bisphosphate levels, and $\mathrm{J}_{\max }$ for Na-dependent glucose transport in intact sheets of tissue in Ussing Chambers

\begin{tabular}{|c|c|c|c|c|c|c|}
\hline \multirow[t]{2}{*}{$\begin{array}{l}\text { Group } \\
(n)\end{array}$} & \multicolumn{2}{|c|}{$\begin{array}{l}\text { Na-dependent glucose transport } \\
\mathrm{J}_{\max }\left(\mathrm{nmol} \cdot \mathrm{min}^{-1} \cdot \mathrm{mg} \mathrm{protein}^{-1}\right)\end{array}$} & \multicolumn{2}{|c|}{$\begin{array}{l}\mathrm{PFK}_{1} \\
\left(\mathrm{nmol} \cdot \mathrm{min}^{-1} \cdot \mathrm{mg} \text { protein }^{-1}\right)\end{array}$} & \multicolumn{2}{|c|}{$\begin{array}{l}\text { Fructose } 2,6 \text {-bisphosphate } \\
\text { (nmol/g dry weight) }\end{array}$} \\
\hline & Jejunum & Ileum & Jejunum & Ileum & Jejunum & Ileum \\
\hline $\begin{array}{l}\text { Control }+ \\
\text { cycloheximide } \\
\text { (4) }\end{array}$ & $54.5 \pm 8.9$ & $32.5 \pm 5.8$ & $72.8 \pm 4.6$ & $61.5 \pm 4.2$ & $11.0 \pm 1.8$ & $9.8 \pm 2.4$ \\
\hline $\begin{array}{l}\text { Diabetic } \\
(6)\end{array}$ & $61.9 \pm 6.1^{\mathrm{a}}$ & $88.6 \pm 8.0^{\mathrm{a}}$ & $40.2 \pm 1.3^{a}$ & $33.0 \pm 3.4^{\mathrm{a}}$ & $6.2 \pm 1.5^{\mathrm{a}}$ & $5.2 \pm 1.0^{\mathrm{a}}$ \\
\hline $\begin{array}{l}\text { Diabetic }+ \\
\text { cycloheximide } \\
\text { (4) }\end{array}$ & $86.1 \pm 13.9^{\mathrm{a}}$ & $108.3 \pm 10.9^{\mathrm{a}}$ & $34.5 \pm 5.4^{\mathrm{a}}$ & $24.5 \pm 5.8^{a}$ & $5.1 \pm 2.0^{\mathrm{a}}$ & $4.6 \pm 2.4^{\mathrm{a}}$ \\
\hline $\begin{array}{l}\text { Diabetic }+ \\
\text { vanadate } \\
\text { (4) }\end{array}$ & $56.8 \pm 5.8^{\mathrm{a}}$ & $39.0 \pm 3.5$ & $79.3 \pm 2.4$ & $60.9 \pm 1.5$ & $13.5 \pm 1.4^{b}$ & $12.4 \pm 1.3^{b}$ \\
\hline
\end{tabular}

Values are means \pm SEM. Treatments were given for $12 \mathrm{~h}$. ${ }^{a} p<0.05$ relative to controls

treatment levels for at least $24 \mathrm{~h}$ after the removal of vanadate and subsequent rise in blood glucose levels. Previous studies have shown that vanadate can be stored in bone, kidney, and liver prior to excretion [22]. This cellular retention of vanadate is likely the reason that Na-dependent glucose transport and $\mathrm{PFK}_{1}$ activity remained at treatment levels following the removal of vanadate treatment, and further supports the hypothesis that vanadate has a direct effect on intestinal enterocytes.

Experimentally produced diabetes is associated with mucosal hypertrophy and increased food intake [23]. The enhanced glucose transport seen in diabetes has been suggested to occur partially as a result of the increased dietary carbohydrate delivery to the intestinal lumen [24]. Although vanadate supplementation suppresses food intake [8], it is unlikely that the results we observed on intestinal Na-dependent glucose transport and $\mathrm{PFK}_{1}$ activity were due to the anorectic effect of vanadate, as diabetic animals fasted for $12 \mathrm{~h}$ did not show an improvement of either parameter.

Conflicting data exists as to the effects of oral vanadate on intestinal glucose transport. We found that the oral dose of vanadate used in this study $(0.5$ $\mathrm{mg} / \mathrm{ml}$ ) rapidly reduced $\mathrm{Na}$-dependent glucose transport in both jejunum $(48 \mathrm{~h})$ and ileum $(12 \mathrm{~h})$. This is in conflict with Hajjar et al. [25] who found that oral vanadate $(0.3 \mathrm{mg} / \mathrm{ml})$ stimulated D-glucose uptake, although 3-0-methyl glucose uptake was reduced. This may be related to two factors. First, Hajjar et al. [25] used orthovanadate for a period of 30 days, whereas in this study the effects of vanadium pentoxide over a period of 7 days were examined. These two compounds have different solubilities, toxicity, and speed of elimination [26], which would likely result in different concentrations of intracellular vanadate. Secondly, Hajjar et al. [25] performed the study on normal rats, whereas we examined the effect of oral vanadate on diabetic rats. In our earlier study, we demonstrated that oral vanadate had little effect on normal tissue [8].

Na-dependent glucose transport in the small intestine is dependent upon the potential difference and sodium electrochemical gradient across the brush border membrane. In agreement with previous studies [27], we found an increase in intestinal PD (potential difference) and $\mathrm{Na}, \mathrm{K}-\mathrm{ATPase}$ activity in diabetic animals. Vanadate has been shown to inhibit $\mathrm{Na}, \mathrm{K}$-ATPase activity when perfused directly into the intestine at a concentration of 0.01 to $1 \mathrm{mmol} / \mathrm{l}$ [20]. Thus, the reduction in Na-dependent glucose transport we observed may have been due to a vanadate-induced dissipation of the sodium electrochemical gradient. However, it is very difficult to determine the intracellular concentrations of vanadate in vivo, as under physiological conditions, internalized $\mathrm{VO}_{3^{-}}$(a potent $\mathrm{Na}, \mathrm{K}$-ATPase inhibitor) is reduced intracellulary to $\mathrm{VO}^{2+}$, a species that is very ineffective in inhibiting the enzyme [28]. Previous studies have shown oral vanadate given at a concentration of $0.05 \mathrm{mg} / \mathrm{ml}$ to be present in the intestine at a concentration of $49 \mu \mathrm{g} / \mathrm{gm}$ after 6 weeks of treatment [29]. In our study we did not observe a reduction in 
$\mathrm{Na}, \mathrm{K}-\mathrm{ATPase}$ enzyme activity until after $48 \mathrm{~h}$ of vanadate treatment, which paralleled the changes in jejunal Na-dependent glucose transport, but occurred $36 \mathrm{~h}$ after ileal glucose transport had been reduced. This would make it unlikely that the rapid reduction in ileal glucose transport was due to a vanadate-induced inhibition of Na,K-ATPase activity. To confirm this we measured in vivo basal intestinal $\mathrm{PD}$, which directly reflects the electrochemical driving (Na,K-ATPase) force for sodium-coupled transport. Basal PD was not affected by vanadate treatment. However, an accurate measurement of not only the total intracellular vanadate concentration, but also its oxidative state would be necessary to determine if orally ingested vanadate is actually inhibiting $\mathrm{Na}, \mathrm{K}$ ATPase activity.

Increased glucose transport seen in STZ-induced diabetic rats is accompanied by a premature expression of SGLT, protein and mRNA by enterocytes along the crypt-villus axis in jejunum and ileum [30]. In the jejunum, glucose transporter induction by diet occurs initially in the crypts and progresses up the villus as cells migrate [31]. In our study, the effects of vanadate in the jejunum appear to follow this pattern. Normalization of jejunal Na-dependent glucose transport occurred over a period of $48 \mathrm{~h}$ and may have reflected the time it took for cells in the crypt to respond to the signal produced by vanadate supplementation, alter their expression of SGLT, and migrate up the villus. However, the ileal response to vanadate treatment was distinctly different from that of the jejunum. The rapid down-regulation of ileal glucose transport indicates that enterocytes in the ileum have the ability to alter the functional activity of existing glucose transporters. Further work will have to be done to determine if this functional reduction in ileal glucose transport also involves a reduction in SGLT, protein in the brush border membrane.

Vanadate-treated animals demonstrated a large decrease in $\mathrm{K}_{\mathrm{m}}$ at both the intact tissue level and at the brush border, indicating an increased affinity of the glucose transporter for glucose in both jejunum and ileum. Glucose transporter affinity may be altered by membrane physical composition [32], and there is evidence that vanadate alters polyunsaturated fatty acid content in membranes, possibly through changes in cholesterol and lipid biosynthesis [33]. Another possibility is that vanadate may alter the expression of the recently described Na-dependent glucose transporter regulatory protein [34]. This regulatory subunit has been proposed to be responsible for mediating nutritional and hormonal signals for the regulation of SGLT, functional activity [34]. The presence of such a regulatory subunit may allow the intestine to rapidly adapt to changing luminal nutrient loads, i. e. increasing the functional expression of a low affinity transporter when large amounts of nutrients are present and switching to a high affinity transporter when nutrient levels decrease, simply by altering the association between the regulatory subunit and the catalytic SGLT, protein. Oral vanadate reduces food intake [8], thus, a switch to a higher affinity transporter may be a physiological response to decreased luminal nutrients. It is currently unknown, however, if vanadate has any effect on expression of this regulatory subunit.

Intestinal enterocytes have a high glycolytic activity [35]. The reaction catalysed by $\mathrm{PFK}_{1}$ is the key regulatory step in the control of enterocyte glycolysis and this enzyme itself is activated by micromolar concentrations of fructose 2,6-bisphosphate [36]. Enterocytes from diabetic rats show a decrease in cellular concentrations of fructose 2,6-bisphosphate [37], which is accompanied by a marked reduction in the rate of glycolysis, and a diminished activity of $\mathrm{PFK}_{1}$ [4]. Our findings are in agreement with these studies. Furthermore, data from this study clearly demonstrate that oral vanadate can rapidly stimulate $\mathrm{PFK}_{1}$ activity and increase cellular concentrations of fructose 2,6-bisphosphate. The mechanism by which vanadate increases fructose 2,6-bisphosphate concentrations is unknown. The concentration of fructose 2,6-bisphosphate is determined by nutritionally and hormonally induced changes in the activity of the bifunctional enzyme 6-phosphofructo-2-kinase/fructose 2,6-bisphosphatase [38]. This enzyme in turn is regulated via phosphorylation/dephosphorylation reactions. It is unlikely that vanadate has a direct action on 6-phosphofructo-2-kinase/fructose 2,6-bisphosphatase, as in vitro experiments have shown vanadate inhibits the kinase activity of the purified enzyme without modifying the phosphatase activity [39]. Thus, while there is evidence that vanadate treatment is able to restore cellular fructose 2,6-bisphosphate to normal levels in diabetic rats [40] and to induce fructose 2,6-bisphosphate production in cultured rat hepatocytes [41], the mechanism remains to be elucidated.

The findings in this study are in agreement with those studies showing that vanadate can stimulate overall intestinal glucose metabolism [25, 42]. In fact, it has been suggested previously that there is a relationship between glucose metabolism and glucose transport in the intestine [43]. Data from this study showing changes in $\mathrm{PFK}_{1}$ activity and fructose 2,6-bisphosphate levels to precede and parallel glucose transport changes also suggests a possible relationship.

In conclusion, oral vanadate treatment rapidly reduces glucose transport and restores 6-phosphofructo-1-kinase activity and fructose 2,6-bisphosphate levels to normal values in the intestine of diabetic rats. This would have the overall effect of increasing glucose utilization within the enterocyte and thus decreasing overall glucose absorption. In addition, both transport and $\mathrm{PFK}_{1}$ activity remain at treat- 
ment levels following the removal of vanadate. Thus, oral vanadate treatment can have prolonged beneficial effects on intestinal function and may prove useful as oral adjunctive diabetic therapy.

Acknowledgements. Dr. Fedorak is a recipient of a Clinical Investigatorship Award from the Alberta Heritage Foundation for Medical Research. Dr. Madsen is the recipient of a postdoctoral Fellowship Award from the Medical Research Council of Canada. These studies were supported by grants from the Alberta Heritage Foundation for Medical Research, Medical Research Council of Canada, and the Muttart Foundation for Diabetic Research.

\section{References}

1. Fedorak RN, Chang EB, Madara JL, Field M (1987) Intestinal adaptation to diabetes. Altered Na-dependent nutrient absorption in streptozotocin-treated chronically diabetic rats. J Clin Invest 79:1571-1578

2. Maenz DD, Cheeseman CI (1986) Effect of hyperglycaemia on D-glucose transport across the brush border and basolateral membrane of rat small intestine. Biochem Biophys Acta 860:277-285

3. Csaky TZ, Fischer E (1981) Intestinal sugar transport in experimental diabetes. Diabetes 30:568-574

4. Jamal A, Kellett GL (1983) Regulation of mucosal phosphofructokinase in the small intestine of the streptozotocin-diabetic rat. Diabetologia 25:355-359

5. Heyliger CE, Tahiliani AG, McNeill JH (1985) Effect of vanadate on elevated blood glucose and depressed cardiac performance of diabetic rats. Science 227:1471-1477

6. Brichard SM, Bailey CJ, Henquin JC (1990) Marked improvement of glucose homeostasis in diabetic ob/ob mice given oral vanadate. Diabetes 39:1326-1332

7. Meyerovitch J, Rothenberg P, Shechter Y, Bonner-Weir S, Kahn CR (1991) Vanadate normalizes hyperglycaemic in two mouse models of non-insulin-dependent diabetes mellitus. J Clin Invest 87:1286-1294

8. Madsen KL, Porter VM, Fedorak RN (1993) Oral vanadate reduces $\mathrm{Na}$-dependent glucose transport in rat small intestine. Diabetes 42:1126-1132

9. Hajar J, Dobish M, Tomicic T (1989) Reversal by vanadate of the effect of diabetes on intestinal growth and transport. Diabetes Res 10:139-141

10. Fedorak RN, Cheeseman CI, Thomson ABR, Porter V (1991) Altered glucose carrier expression: mechanism of intestinal adaptation during streptozotocin-induced diabetes in rats. Am J Physiol 261:G585-G591

11. Radominski-Pyret A, Kraus-Friedmann N, Lester R, Little J, Denkins Y (1982) Rapid stimulation of Na,K-ATPase by glucagon, epinephrine, vasopressin and cAMP in perfused rat liver. FEBS letters 141:56-58

12. Bradford MM (1976) A rapid and sensitive method for the quantitation of microgram quantities of protein utilizing the principle of protein-dye binding. Anal Biochem 72:248-254

13. Ling KH, Marcus F, Lardy HA (1965) Purification and some properties of rabbit skeletal muscle phosphofructokinase. J Biol Chem 240:1893-1899

14. Hussey CR, Liddle PF, Ardron D, Kellett GL (1977) The isolation and characterization of differentially phosphorylated fractions of phosphofructokinase from rabbit skeletal muscle. Eur J Biochem 80:497-506
15. Van Schaftingen E, Lederer B, Bartrons $R$, Hers $H G$ (1982) A kinetic study of pyrophosphate:fructose 6-phosphatephosphotransferase from potato tubers. Eur J Biochem 129:191-195

16. Kessler M, Acuto O, Storelli C, Mjrer H, Muller M, Semenze $\mathrm{G}$ (1978) A modified procedure for the rapid preparation of efficiently transporting vesicles from small intestinal brush border membranes. Biochim Biophys Acta 506:136-154

17. Hopfer U, Nelson K, Penotto J, Isselbacher KJ (1973) Glucose transport in isolated brush border membrane from rat small intestine. J Biol Chem 248:25-32

18. Crouzoulon G, Dandrifosse G (1979) Dietary regulation of fructose metabolism in the intestine and in the liver of the rat: time response and effect of cycloheximide. Eur J Biochem 10:439-447

19. Meddings JB, Scott RB, Fick GH (1989) Analysis and comparison of sigmoidal curves: application to dose-response data. Am J Physiol 257:G982-G989

20. Kellett GL, Barker ED (1989) The effect of vanadate on glucose transport and metabolism in rat small intestine. Biochem Biophys Acta 979:311-345

21. Sekar N, Kanthasamy A, William S, Subamanian S, Govindasamy $S(1990)$. Insulinic actions of vanadate in diabetic rats. Pharmacological Res. 22:207-217

22. Underwood EJ (1977) Vanadium in trace elements in human and animal nutrition. Academic Press, New York, pp 388-397

23. Schedl HP, Wilson HD (1971) Effects of diabetes on intestinal growth in the rat. J Exp Zool 176:487-496

24. Fedorak RN, Thomson ABR, Porter VM (1990) Adaptation of intestinal glucose transport in rats with diabetes mellitus occurs independent of hyperphagia. Can J Physiol Pharmacol 69:1143-1148

25. Hajjar, JJ, Dobish MP, Tomicic TK (1989) Effect of acute and chronic vanadate administration on sugar transport in rat jejunum (42827) PSEBM 190:35-41.

26. World Health Organization (1988): Vanadium. Environmental Health Criteria. 81/Geneva, World Health Organization

27. Debnam ES, Ebrahim HY (1989) Diabetes mellitus and the sodium electrochemical gradient across the brush border membrane of rat intestinal enterocytes. J Physiol 123:453459

28. Cantley LC, Cantley LG, Josephson L (1978) A characterization of vanadate interactions with the $\mathrm{Na}^{+}-\mathrm{K}^{+}-\mathrm{AT}$ Pase: mechanistic and regulatory implications. J Biol Chem 253:7461-7468

29. Parker RDR, Sharma RP (1978) Accumulation and depletion of vanadium in selected tissues of rats treated with vanadyl sulfate and sodium orthovanadate. J Env Path Tox 2:235-245

30. Burant CF, Flink S, DePaoli AM, Chem J, Lee W, Hediger MA, Buse JB, Chang EB (1994). Small intestine hexose transport in experimental diabetes. J Clin Invest 93:578585

31. Ferraris RP, Diamond JM (1992) Crypt-villus site of glucose transporter induction by dietary carbohydrate in mouse intestine. Am J Physiol 262:G1069-G1073

32. Meddings JB, DeSouza D, Goel M, Theisen S (1991) Glucose transport and microvillus properties along the cryptvillus axis of the rabbit. J Clin Invest 85:1099-1107

33. Oster MH, Llobet JM, Domingo JL, Keen CL (1991) Short-term effects of vanadate treatment in diabetic rats. FASEB J 5:3141

34. Veyhl M, Spangenberg J, Puschel B et al. (1993) Cloning of a membrane associated protein which modifies activity and 
properties of the $\mathrm{Na}^{+}-\mathrm{D}$-glucose cotransporter. J Biol Chem 268:25041-25053

35. Towler CM, Pugh-Humphreys GP, Porteus JW (1978) Characterization of columnar absorptive epithelial cells isolated from rat jejunum. RRR 29:53-75

36. Kellett GL, Jamal A, Robertson JP, Wollen N (1984) The acute regulation of glucose absorption, transport and metabolism in rat small intestine by insulin in vivo. Biochem $\mathrm{J}$ 219:1027-1035

37. Rossi I, Sanchez-Arias, Feliu JE (1990) Effect of streptozotocin diabetes on the glycolytic flux and on fructose 2,6-bisphosphate levels in isolated rat enterocytes. Metabolism 39:882-885

38. Hue L, Rider MH (1987) Role of fructose 2,6-bisphosphate in the control of glycolysis in mammalian tissues. Biochem J 245:313-324
39. Kountz PD, McCain RW, El-Maghrabi MR, Pilkis SJ (1986) Arch Biochem Biophys 251:104-113

40. Gil J, Miralpeiz M, Carreras J, Bartrons R (1988) Insulinlike effects of vanadate on glucokinase activity and fructose 2,6-bisphosphate levels in the liver of diabetic rats. J Biol Chem 263:1868-1971

41. Miralpeix M, Katx NR, Bartrons R (1990) Effects of vanadate on 6-phosphfructo-2-kinase activity and fructose 2,6bisphosphate levels in cultured rat hepatocytes. Cell Bioch Func 8:237-241

42. Tolman EL, Barris E, Burns M, Pansini A, Partridge R (1979) Effects of vanadium on glucose metabolism in vitro. Life Sciences 25:1159-1164

43. Wollen N, Kellett GL (1988) Regulation of glucose homeostasis in rat jejunum by despeptapeptide-insulin in vitro. Gut 29:1064-1069 